\title{
Hidden Truths from Eden: Esoteric Readings of Genesis I-3, edited by Caroline Vander Stichele and Susanne Scholz
}

Semeia Studies 76 | Atlanta: SBL Press, $2014 \mid 298$ pages | ISBN: 978-I-62837-013-3 (hardcover) \$51.95; ISBN: 978-I-62837o I 2-6 (softcover) $\$ 36.95$

Stichele and Scholz, the editors of this volume, who

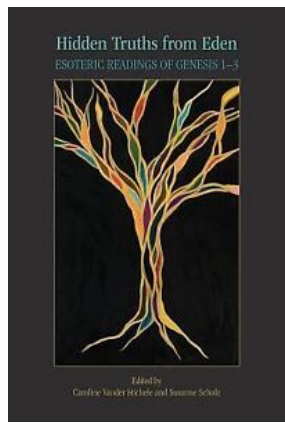
hail from institutions on the eastern and western sides of the Atlantic respectively, express a remedial agenda for their volume. Their feeling is that the dominant historical-critical paradigm in biblical studies has sidelined the reading of the Bible for its "spiritual" sense, despite the deep heritage of such reading within and without the Christian church. More specifically, with exceptions such as Elaine Pagels's research in early Gnosticism, "the historicized quest of biblical meaning" has involved "a broad disregard for studying the extensive interpretation history of esoteric readings of the Bible" (vii). Their hope is that this collection of essays investigating a range of esoteric interpretations of Genesis $\mathrm{I}-3$, ancient and modern, might assist "esoteric bibli[c]al readings [to] become part of the academic discourse in biblical studies," befitting the "post-postmodern period" in which we live 
(let's hope that's the last "post") and bringing a corrective to "the literalist malady" (viii).

Noting the fraught definition of "esoteric" in their introduction, Stichele and Scholz explain the term etymologically as a hermeneutic that is concerned with the inner life of the reader, and we might add that it suits the idea of an inner or hidden meaning of the text equally well (2). The addition of examples is helpful. Seeing the mention of "alchemy, astrology, Anthroposophy, Gnosticism, Neoplatonism, Rosicrucianism, or Christian Theosophy," along with names such as Jacob Böhme, Emanuel Swedenborg, Helena Blavatsky, and Rudolph Steiner will help most readers gain some sense of the phenomenon under discussion, however blurry the boundary that embraces them. As the examples indicate, the focus is on Western and Judeo-Christian esoteric examples. The volume therefore embodies a twofold aim: I) to introduce esoteric hermeneutics "to the academic field of biblical studies" and prompt corresponding studies of other biblical texts, and 2) "to awaken interest in esoteric perspectives, methodologies, and thinkers" (3). We may readily class this set of studies within the broader contemporary field of reception history, recognising in this work the latter's attraction to streams of interpretation that have suffered neglect or positive repression under modern research models or traditions.

The collection is structured in four sections following the introduction, the first three of which correspond to three broad historical periods: the late antique or patristic period, the middle ages through the Renaissance, and finally the eighteenth through the twentieth centuries. The fourth section consists of two responses from respected scholars of esotericism, whose effect is very much to flavour the reader's final impressions from the book.

In part I, the first essay by Anna Rebecca Solevåg offers an interpretation of the apocryphal Acts of Andrew, dating from about the 2 nd- 3 rd century CE (9). Solevåg helpfully clarifies the definition of esotericism ( 10 ), then studies the Acts of Andrew from both class and gender angles (I2), concluding that this text, historically interpreted as a call to sexual renunciation, is more fully understood in the broader category of esotericism (22-23).

Almost the defining text of ancient Gnosticism, the Apocryphon of John, elicits the second essay by Tuomas Rasimus. Current dispute over the meaning and viability of the term "Gnosticism" compels Rasimus to define it further, and he opts to "speak of Classic Gnosticism whose chief representative is the Apocryphon of John" (32). Rasimus asks why it is an eagle in this version of the story, rather than the serpent, that persuades Adam and Eve 
to eat from the Tree of Knowledge (35), finding that the eagle is a Roman imperial symbol for Christ.

The third essay in Part One examines Origen's interpretation of the "garments of skins" given to Adam in Eve in Gen 3:2I, late in the Eden narrative. Author Peter Martens succeeds in showing that Origen is drawn to the idea that a primordial, spiritual humanity is first "clothed" with human flesh at this point in the story (57), yet struggles for interpretive consistency, and has to dechronologize the passage to allow Gen 2:7 and Gen 3:2 I to refer to the "incarnation" of pre-existing human souls (67-70). We feel prompted to ask the taxonomic question once again: "Is Origen also among the Gnostics?"

Part 2, "Zoharic, Kabbalistic, and Alchemical Speculations," is inherently broad, and opens with an essay by Elliot R. Wolfson focusing on how gender is presented in the Zohar, the defining text of Jewish kabbalah mysticism, emerging from late medieval Spanish Judaism and showing connections to earlier rabbinic speculation (87). Jewish kabbalah includes the core belief that the most basic entities of reality "are the manifold permutations of the twenty-two Hebrew letters, themselves enfolded in the Tetragrammaton, identified as the mystical essence of the Torah" (94). Wolfson here rejects the sympathetic view that the Zohar embodies a truly balanced valuing of male and female, instead finding it androcentric ( $\left.\mathrm{IO}_{3}-4\right)$. More relevant to me was Peter J. Forshaw's essay on the incorporation of kabbalistic mysticism into Italian Renaissance Christianity, particularly through the prodigious, though short-lived, Pico della Mirandola (I463-I 494). Forshaw reveals the way the letters of the very first word of the Hebrew Bible, בראשית, were understood to communicate hidden realities; Mirandola turned this stock kabbalistic device in a loosely Trinitarian Christian direction (I28-I 30). Mirandola epitomizes the ongoing esoteric fascination with the opening chapters of Genesis, perceived as cryptic repository of the universe's secrets (I32), in an essay that helped this reader better understand the flow of the history of esoteric thought in the West.

A less kabbalistic than Neoplatonist and perhaps Pseudo-Dionysian emanationism appears in the treatise Philosophia ad Atheniensis, treated in the next essay by Georgiana Hedesan. The Philosophia ad Atheniensis was attributed early on to the founding figure of early modern alchemical philosophy, Paracelsus ( I 493-I 54I), though the attribution is now debated. "The key to Ad Atheniensis's understanding of creation lies in the uncreated mysterium magnum ('great mystery') used by God to make the world," Hedesan explains (I 47). The mysterium magnum appears to combine the passive role 
of primordial, formless matter with an active role akin to Philo's Logos as an agent of creation. Though "the vision of Ad Atheniensis is fraught with paradoxes," it had in common with other such esoteric interpretations the quest for "an invisible Genesis lying with the written one" (I 54) Hedesan's explanation helped clarify the use of Mysterium Magnum as the title of a famous esoteric work by the influential mystic Jakob Böhme (I 575?-I624). Having read the latter work, I strongly recommend reading an introduction like Hedesan's before tackling the primary documents.

Part 3's opening essay follows on smoothly from the two preceding essays. Here one of the editors, Susanne Scholz, studies "Esoteric Interpretations of Gen I-3 by E. Swedenborg, R. Steiner, and S. D. Fohr," thus touching on each century from the eighteenth up to the present day. Their post-mortem neglect by mainstream scholarship exemplifies, in Scholz's mind, the sidelining of influential esoteric interpretations of Genesis in academic biblical studies. She is drawn to Swedenborg's view that "spiritual understanding is the exclusive goal of biblical exegesis," in contrast to "the dominant historicalliteral paradigm" (I70-7I). Steiner's influence persists in the Steiner schools that are still dotted around the Australian landscape at least; I have lived within walking distance of one in each of my last two homes. Samuel D. Fohr's "esoteric reading of Gen 2-3" ( I 86) provides a link between past and present, since Fohr is author of the final essay in the volume.

The final two essays in part 3 are narrower in scope. First, László-Attila Hubbes offers a study of the philosophy of the original purity, fall and ultimate restoration in the thought of eclectic Hungarian thinker Béla Hamvas (I 897-I 968). Hubbes admits that the connection with Genesis I-3 is only indirect (204), and it stretches the volume title's implied scope. Hamvas appears to have melded gnostic, kabbalistic, and classical philosophical ideas into a quasi-Christian redemption myth that envisions a restored golden age (2 I 2-I 5). Then Hugh R. Page, Jr. sets out in the following essay to initiate a program for the study of African and Diaspora African esotericism. He expresses his aim "to start a scholarly conversation" in a barely touched field, though he has to admit that the connection with Gen I-3 remains to be explored (229-30), a deficit that throws in even greater doubt whether this essay has a clear claim to membership in the collection.

The Responses in Part Four have a kind of meta role in relation to the preceding nine essays. The first, Elaine Pagels's "Strategies of Esoteric Exegesis," reads rather like the editorial preview found in many edited volumes, but with a more practised eye than most. Pagels's own expertise is oriented 
towards the ancient part of the volume's historical sweep, but she identifies themes recurring in esoteric interpretations across the centuries spanned, such as the androcentric undertones thwarting the superficial male-female dualism in many esoteric interpretations (240), and the dispersal of Jewish mystical ideas into subsequent Christian sources (243-44). Resisting Scholz's disillusionment, Pagels retains a place for investigation of "the political, social, and historical circumstances and concerns of each exegete and of the audience each addresses," i.e. for historical-critical investigation (244).

Finally, Samuel D. Fohr's "Esotericism and Biblical Interpretation" is a both-sides or both-emic-and-etic study, after Fohr's esoteric material itself formed a subject for investigation earlier in the book (I86-I9I). This essay reflects the well-schooled thinking of a mind steeped in the material at hand, along with subtle signs of an insider's commitments. He is willing to be critical of the preceding essays, e.g., criticizing Hugh Page for equating "esoteric" with "occult," whereas he considers that "the first deals with the spiritual while the second deals with the worldly" (262). And he too, like Pagels, retains a place for historical criticism (266). For the purpose of understanding esotericism, though, you might find his characterization thought-provoking:

In the exoteric approach, God is up in the heavens, while we are down here on earth, and our goal is to be loving servants who will finally meet God in heaven after we die. In the esoteric approach, we are nothing other than God, and the spiritual goal is to become aware of this.... From the exoteric point of view, God is in the world, in heaven, while from the esoteric point of view the world is in God. (247)

Such nutshell statements are vulnerable to being simplistic and one might feel that there are other theological-philosophical possibilities. The following context adds nuance to this nonetheless provocative twofold antithesis. Fohr's essay, and the collection as a whole, have the value of drawing scholarly attention to what does remain, still, an undeservedly isolated and neglected tradition within the study of biblical reception. Esoteric traditions from second-century Gnosticism through medieval kabbalism to Rudolf Steiner and beyond have both been consistently attracted to the power and pregnant imagery of the early chapters of Genesis, in particular the Eden narrative of Gen. 2:4-3:24, and have regularly reasserted their influence on popular, 
scientific, and religious thought and culture. For these reasons alone they deserve the attention they receive in this book. Its content is selective, and much ground remains to be turned over, but this volume is a stimulating beginning.

Andrew Brown

Melbourne School of Theology 